\title{
Molecular, Ultrastructural, and Biological Characterization of Pennsylvania Isolates of Plum pox virus
}

\author{
William L. Schneider, Vernon D. Damsteegt, Fred E. Gildow, Andrew L. Stone, Diana J. Sherman, \\ Laurene E. Levy, Vessela Mavrodieva, Nancy Richwine, Ruth Welliver, and Douglas G. Luster
}

First, second, fourth, fifth, and tenth authors: United States Department of Agriculture (USDA) Agricultural Research Service, Foreign Disease-Weed Science Research Unit, 1301 Ditto Ave., Ft. Detrick, MD 21702; third author: Department of Plant Pathology, Penn State University, Buckhout Laboratory, University Park, PA 16802-5023; sixth and seventh authors: USDA Animal and Plant Health Inspection Service, PPQ-CPHST National Plant Germplasm and Biotechnology Laboratory, Beltsville, MD 20705; and eighth and ninth authors: Pennsylvania Department of Agriculture, Harrisburg.

Accepted for publication 13 January 2011.

\begin{abstract}
Schneider, W. L., Damsteegt, V. D., Gildow, F. E., Stone, A. L., Sherman, D. J., Levy, L. E., Mavrodieva, V., Richwine, N., Welliver, R., and Luster, D. J. 2011. Molecular, ultrastructural, and biological characterization of Pennsylvania isolates of Plum pox virus. Phytopathology 101:627-636.

Plum pox virus (PPV) was identified in Pennsylvania in 1999. The outbreak was limited to a four-county region in southern Pennsylvania. Initial serological and molecular characterization indicated that the isolates in Pennsylvania belong to the D strain of PPV. The Pennsylvania isolates were characterized by sequence analysis, electron microscopy, host range, and vector transmission to determine how these isolates related to their previously studied European counterparts. Genetically,

Pennsylvania (PPV-Penn) isolates were more closely related to each other than to any other PPV-D strains, and isolates from the United States, Canada, and Chile were more closely related to each other than to European isolates. The PPV-Penn isolates exist as two clades, suggesting the possibility of multiple introductions. Electron microscopy analysis of PPV-Penn isolates, including cytopathological studies, indicated that the virions were similar to other Potyvirus spp. PPV-Penn isolates had a herbaceous host range similar to that of European D isolates. There were distinct differences in the transmission efficiencies of the two PPV-Penn isolates using Myzus persicae and Aphis spiraecola as vectors; however, both PPV-Penn isolates were transmitted by $M$. persicae more efficiently than a European D isolate but less efficiently than a European M isolate.
\end{abstract}

Plum pox virus (PPV) is a significant problem in stone fruit around the world. PPV was originally described in Eastern Europe, from where it has spread across much of the continent. Long-distance spread of the virus has generally been associated with human movement of PPV-infected plant material (8). Spread of PPV within and among orchards occurs by aphid vectors $(14,15)$. There are seven recognized strains of PPV. Three strains, PPV-D, PPV-M, and PPV-C, were described from Europe $(24,29)$. PPV El Amar (PPV-EA) was originally described in Egypt (40), and PPV-W was most recently described from Canada (19). Two recombinant strains of PPV have been described, PPV-Rec and PPV-T $(12,33)$. The D strain of PPV was the first described and the most widespread strain of PPV. In 1992, PPV was first reported in the western hemisphere, in Chile (16). In 1999, PPV was discovered in Adams County, PA (22). This outbreak was determined to be limited to a four-county area in southern Pennsylvania. PPV was reported in the Niagara region of Ontario, Canada in 2000 (38) and in Argentina in 2004 (5). Most recently, PPV was identified in Michigan and New York $(14,34)$. All of the strains found in the western hemisphere are D strains, with the exception a W isolate (18) and a PPV-Rec isolate found in Canada (25).

PPV is a member of the family Potyviridae, with a 9.8-kb positive-sense RNA genome. The genome is translated as a single

Corresponding author: W. L. Schneider;

E-mail address: william.schneider@ars.usda.gov

doi:10.1094/PHYTO-09-10-0256

This article is in the public domain and not copyrightable. It may be freely reprinted with customary crediting of the source. The American Phytopathological Society, 2011 polyprotein, which is cleaved into 10 individual functional proteins post-translation. PPV has been very well characterized at the molecular level $(10,23)$. The different PPV strains show considerable sequence conservation among the isolates of a given strain but have considerable sequence divergence among strains $(18,37)$. The genomic changes among strains are spread relatively evenly across the genome (26), with the most variable region of the genome being the $5^{\prime}$ end of the coat protein gene (37).

Despite the sequence conservation within PPV strains, individual isolates can show considerable biological diversity. For example, a severe isolate of the $M$ strain has been described and characterized, causing aggressive necrogenic symptoms on peach (2). More severe isolates of the D strain have also been described $(4,28)$. D strain isolates have demonstrated differences in host range (6) and aphid vectors $(11,20)$. This is not entirely surprising, because small differences in sequence can have drastic effects on Potyvirus biology. HC-Pro mutations are capable of altering replication, cell-to-cell movement, and aphid transmission $(12,13,30,31)$. Mutations in the CI gene are responsible for effects in replication and viral movement $(3,9)$ and mutations in the coat protein have effects on aphid transmission (1). Single mutations also can have significant effects on PPV biology. For example, a single mutation in the NIb gene caused significant differences in replication efficiency in pea (39), and a single mutation in the PPV HC-Pro gene abolished both synergism and silencing suppression (13).

The approach to dealing with the outbreak of PPV in Pennsylvania was an eradication effort directed by the Pennsylvania Department of Agriculture and the United States Department of Agriculture (USDA) Animal and Plant Health Inspection Service (APHIS). This approach was chosen in part based on the knowledge that the isolates in Pennsylvania are PPV-D isolates, 
which current scientific literature suggests should be less aggressive and more difficult to transmit. With this in mind, the objective of this research was to characterize the Pennsylvania isolates of PPV (PPV-Penn isolates) in order to determine how they related to previously described PPV-D isolates, partially testing the validity of the assumption that all PPV-D isolates behave similarly. The PPV-Penn isolates were sequenced completely, analyzed by electron microscopy (EM), and biologically characterized in terms of their host range and aphid transmissibility.

\section{MATERIALS AND METHODS}

Geographic distribution of PPV in Pennsylvania. Prunus spp. orchard blocks in Pennsylvania were identified, catalogued, and incorporated into a GIS layer using ArcMap software (ESRI, Inc.). The extent for each Prunus orchard block was captured using Corvallis Microtechnologies March II series global positioning system receivers. A point feature class was then created based on the centroids derived from the spatial extents of each orchard block. The coordinate system used for this feature class is Universal Transverse Mercator zone $18 \mathrm{~N}$, North American Datum 83.

Orchard surveys were conducted annually for all available orchard blocks, combining leaf sampling with subsequent enzyme-linked immunosorbent assay (ELISA) analysis using 5BIVIA monoclonal antibodies. Positive samples were confirmed with further ELISA analysis and immunocapture reverse-transcription polymerase chain reaction (RT-PCR) using the $3^{\prime}$ untranslated region and coat protein regions (22). In 1999, orchard sampling was done on a simple transect through the orchard. Beginning in 2000, orchards were surveyed using a hierarchical sampling protocol which was designed to yield an estimate of incidence at the tree level, based on incidence at the sampled group level (17). A joint USDA/Pennsylvania Department of Agriculture eradication program instituted in 2000 required that all orchard blocks containing positive trees be removed. In addition, any other susceptible trees within $500 \mathrm{~m}$ of that positive block had to be removed, and no new plantings were permitted in or around these sites, based on a moratorium determined by the USDA-APHIS PPV science panel. Any blocks that did not need to be removed were resampled each year they remained standing. Survey and ELISA testing of Prunus trees in non-orchard settings were also carried out each year, beginning in 2000 on a small scale and developing into a saturated survey by 2002. Sites of positive trees in non-orchard residential settings were included in the GIS data set.

Isolates and purification. All of the PPV isolates (Fig. 1) used in this study were collected between 1999 and 2003 from infected peach (Prunus persica) or plum $(P$. domestica) trees in Adams County, PA (Penn1 and Penn2), Cumberland County, PA (Penn3, Penn9, Penn10, and Penn12), and York County, PA (Penn6 and Penn8), and maintained by grafting or aphid inoculation of peach seedlings ( $P$. persica 'GF 305'). Isolates Penn10 and Penn11 were recovered via the transplantation of an entire infected tree or shrub (peach for Penn10 and P. glandulosa for Penn11) from Cumberland County and York County, respectively. Three

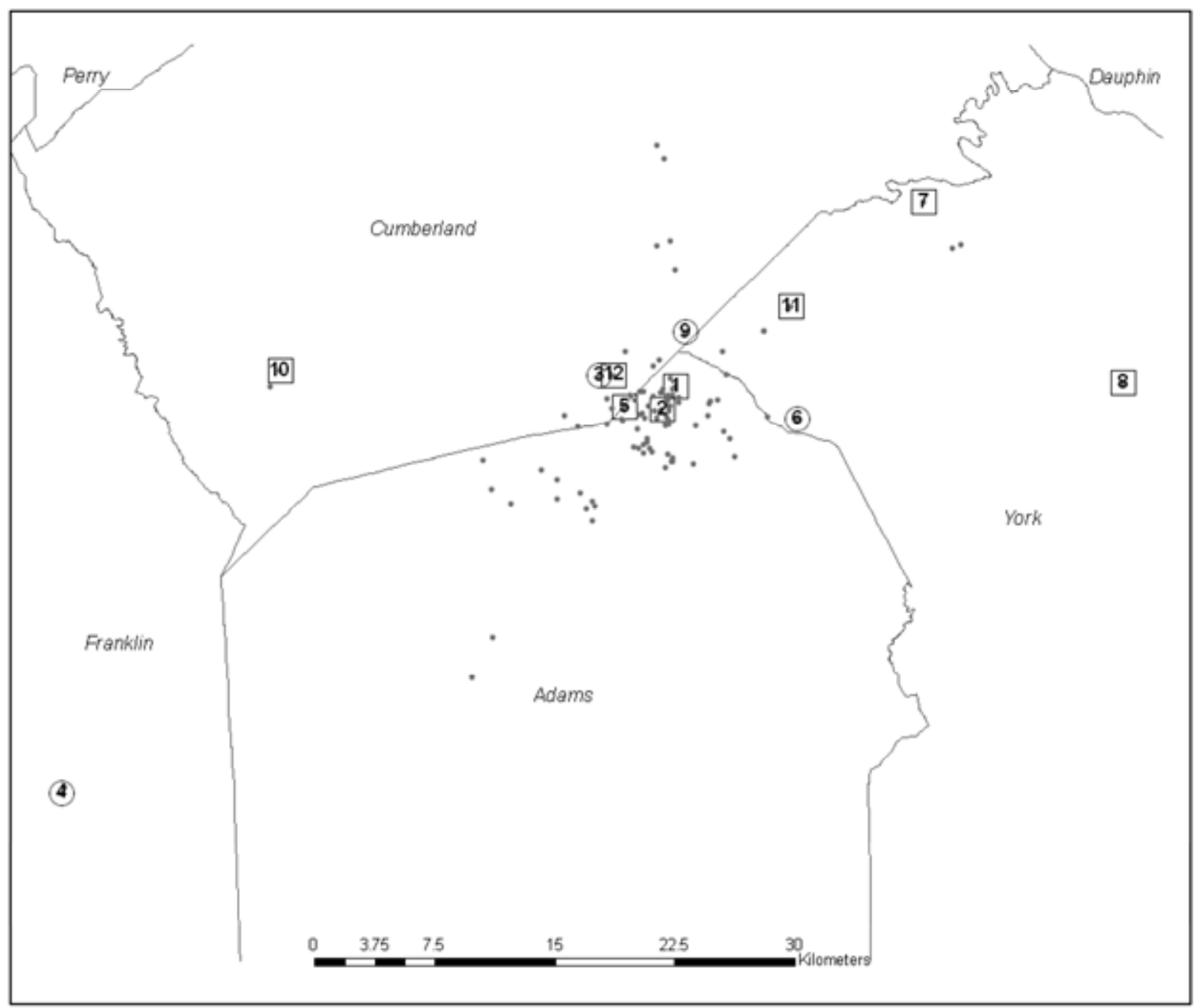

Fig. 1. Map of Plum pox virus (PPV) incidence in Pennsylvania. Sequenced isolates are identified by numbers corresponding to the numbered isolates in the phylogenetic trees. Isolates with squares are representatives of clade A. Isolates with circles are representatives of clade B. 
isolates, one from Franklin County (Penn4), one from Adams County (Penn5), and one from York County (Penn7), came from infected peach fruit (11). All isolates were maintained in the USDA Agricultural Research Service BSL-3 greenhouse facility at Fort Detrick, MD. Several isolates, including Penn3, were transmitted into pea (Pisum sativum 'Colmo') or Nicotiana benthamiana using Myzus persicae or mechanical inoculation as described (39) to provide propagation material for virion purification. PPV virions (Penn3 isolate) were isolated from infected pea or $N$. benthamiana leaves using previously described methods (21) with limited modifications. Briefly, the extraction buffer was $100 \mathrm{mM}$ sodium citrate buffer (with no thioglycerol), $\mathrm{pH}$ 6.7, and the leaf tissues were frozen and ground in liquid nitrogen using a mortar and pestle instead of a blender. RNA was extracted from purified virions using two phenol/chloroform extractions followed by precipitation with two volumes of ethanol and 0.1 volume $3 \mathrm{M}$ sodium acetate, $\mathrm{pH}$ 5.5. Purified virion preps from pea and $N$. benthamiana were compared for infectivity by rub inoculations onto pea, $N$. benthamiana, and peach.

Sequencing. Total RNA for 12 PPV-Penn isolates was extracted from the original tree (Penn10) or from the originally inoculated peach (all others) using previously described methods (39). The total RNA was used as a template for reverse transcription, and the resulting cDNA served as the template for 10 PCR reactions that generated products that covered the full length of the PPV genome, as previously described (39). PCR was conducted using high-fidelity $\mathrm{Taq}$ polymerase. The PCR product was sequenced directly to determine the consensus sequence of each population and to avoid PCR-related errors.

The full-length sequences were assembled using CodonCode aligner (version 2.0; CodonCode Corp. Dedham, MA) and aligned using MEGA 3.1. The sequences of additional D isolates from Canada (AY912058, AY953262, AY953265, and AY912056) and Europe (D13751 and M92280) were added to the alignment $(18,36,37)$. The alignments were phylogenetically analyzed using the branch and bound setting for the maximum likelihood or neighbor-joining analyses of PAUP version 4.10b (Swofford). Some combinations of PPV strains M (M92280), W (AY912055), BOR (AY028309, a PPV-Rec strain)), EA (AM158175 and DQ431465), and SoC (AY184478) were used as outgroups and 1,000 bootstrap replicates were used per analysis. Branches with $<70 \%$ confidence intervals were collapsed. Trees also were constructed for individual genes using the same methods. The Chilean isolates (AF440741 to AF4407416) are included only in the analyses of the $3^{\prime}$ end of the genome, because full-length sequences are not available.

EM. Leaves showing typical symptoms of plum pox were collected from orchard-grown peach and plum trees previously identified as PPV infected by ELISA and PCR. A subset of these leaves was further ELISA tested to verify infection by PPV-D strains. For negative staining and immunolabeling of PPV virions, $\approx 1 \mathrm{~g}$ of infected leaf tissue showing typical vein-clearing symptoms was homogenized in $10 \mathrm{ml}$ of $0.05 \mathrm{M}$ phosphate buffer, filtered through Miracloth, and 1-ml aliquots clarified by microfuge centrifugation. Extracts were stored on ice $\left(4^{\circ} \mathrm{C}\right)$ at all times. For immunotrapping virions, formvar-carbon-coated 300-mesh nickel grids were incubated on 20- $\mu$ l drops of 1:500 diluted polyclonal anti-PPV immunoglobulin $\mathrm{G}(\mathrm{IgG})$ antisera (Bioreba) for $1 \mathrm{~h}$ at $22^{\circ} \mathrm{C}$ (RT). Control treatments consisted of uncoated grids and grids coated with antisera to Prunus dwarf ilarvirus (PDV). Grids were then rinsed three times in buffer and incubated on $20-\mu \mathrm{l}$ drops of plant extract for 1 to $6 \mathrm{~h}$ at $22^{\circ} \mathrm{C}$ or for $16 \mathrm{~h}$ at $4^{\circ} \mathrm{C}$. Following sample incubation, grids were rinsed once in buffer, fixed for $10 \mathrm{~min}$ in $1 \%$ glutaraldehyde, rinsed through five drops of deionized water, stained for $3 \mathrm{~min}$ in $2 \%$ uranyl acetate (UAc), and air dried overnight before examination. To decorate particles with antibody, grids with attached virions were incubated for $30 \mathrm{~min}$ in 1:500 diluted PPV-antibody prior to the
$1 \%$ glutaraldehyde fixation step. For immunogold labeling, formvar-carbon grids were incubated for $2 \mathrm{~h}$ on $20-\mu \mathrm{l}$ drops of sample extract at $4^{\circ} \mathrm{C}$, rinsed in two drops of buffer, incubated for $5 \mathrm{~min}$ in $1 \%$ bovine serum albumin (BSA), and then incubated for $30 \mathrm{~min}$ in 1:500 diluted polyclonal rabbit anti-PPV IgG or antiPDV IgG as a control. Grids were then incubated for $15 \mathrm{~min}$ on drops of $1 \%$ BSA to reduce nonspecific labeling, rinsed five times in buffer, and incubated for $30 \mathrm{~min}$ in $5 \mathrm{~nm}$ of gold-conjugated anti-rabbit antibody (Sigma-Aldrich) diluted 1:1000 in 0.3\% BSA in $0.01 \mathrm{M}$ phosphate buffer $(\mathrm{pH} \mathrm{7.2)}$. Grids were rinsed, fixed, and stained as described above.

For ultrastructural study, 8- $\mathrm{mm}^{2}$ blocks of PPV-infected peach leaf tissue were removed from leaves using a razor blade and immersed in cold $\left(4^{\circ} \mathrm{C}\right)$ fixative containing $1 \%$ formaldehyde and $2 \%$ glutaraldehyde in $0.1 \mathrm{M}$ sodium cacodylate buffer at $\mathrm{pH}$ 7.4. The tissue was then cut into $2-\mathrm{mm}^{2}$ pieces and allowed to fix overnight at $4^{\circ} \mathrm{C}$. Tissue for fixation was selected from the margin of areas of leaf lamina with chlorotic vein clearing or areas showing chlorotic line patterns and rings. Small veins were included in samples. Healthy leaf tissue was fixed in parallel. In addition, leaf tissue from Colmo pea inoculated with PPV isolates originating from field-infected trees was fixed for EM. Following fixation, tissues were rinsed in buffer and post-fixed in $1 \%$ osmium tetroxide for $1 \mathrm{~h}$, rinsed, stained for $1 \mathrm{~h}$ in $2 \%$ aqueous UAc, dehydrated in ethanol to propylene oxide, and embedded over 2 days in epon-araldite plastic. Azure-B-stained semi-thick sections $(0.25 \mu \mathrm{m})$ were used to orient tissues and $60-\mathrm{nm}$ thin sections were contrasted with $2 \%$ uranyl acetate $(30 \mathrm{~min})$ and $0.4 \%$ lead citrate $(15 \mathrm{~min})$. Sections on formvar-carbon grids were observed with a JEM 1200 transmission electron microscope at the Electron Microscope Facility for the Life Sciences at Pennsylvania State University.

For in situ immunogold labeling, leaf tissues were fixed in $1 \%$ formaldehyde, dehydrated to $90 \%$ ethanol, and embedded in L.R. White plastic. Ultrathin sections $(60 \mathrm{~nm})$ were immunogold labeled using anti-PPV IgG and antibody-gold conjugates (Aurion) following the suppliers instructions. Labeled sections were stained and observed as described above.

Herbaceous host range. PPV isolates Penn3 and Penn4 were inoculated into $N$. benthamiana and Colmo pea using $M$. persicae. These infected pea and $N$. benthamiana plants were used as a source for subsequent mechanical or aphid herbaceous host range inoculations. Mechanical and aphid inoculations of herbaceous hosts were done as described (39). Aphid inoculations of herbaceous hosts were done as described (11). Presence or absence of PPV infection was determined by ELISA or RT-PCR, or by back inoculation to peach as described (6).

Aphid transmission. Aphis spiraecola and M. persicae, two confirmed vectors of PPV, were raised as described (11). Both vector species were originally collected in Pennsylvania. PPV isolates Penn4, Penn7 (representing the two clades of Pennsylvania PPV isolates), PPV-22903A (a European D strain isolate from Romania) (7), and a PPV-M strain isolate from Greece (provided by P. Gentit) were verified by sequencing of the coat protein gene. All four isolates were maintained in peach (P. persica 'GF 305') and used as inoculum for a series of aphid-transmission tests. Three replicate experiments were run for both aphid vector species using all four sources of inoculum. Each replicate had 10 inoculated plants. Infected peach leaves showing typical symptom development were detached and placed in a plastic container. The aphids were removed from propagation plants and starved for 30 to $40 \mathrm{~min}$. In separate tests 25 to $50 \mathrm{M}$. persicae or 50 to $100 \mathrm{~A}$. spiraecola were placed on each of 10 individual leaf pieces. The aphids were allowed to feed on the infected leaf pieces briefly, and then the leaf pieces were placed on 2- to 3 -week-old peach seedlings ('Lovell') and the entire plant was caged. After 3 days, the aphids were killed with insecticide. The inoculated seedlings were placed in a greenhouse and observed 
for symptom development for 3 weeks. Symptom development at 3 weeks postinoculation was rated using a 0 -to- 3 scale $(0=$ no symptoms, $1=$ mild mosaic on one or two leaves, $2=$ mild mosaic on a majority of leaves or leaf curling or severe mosaic symptoms on one or two leaves, and $3=$ leaf curling and severe mosaic symptoms on most leaves). At that time, leaf samples were taken and tested for PPV titer using real-time RT-PCR as previously described (32). Differences in transmission were analyzed by analysis of variance.

\section{RESULTS}

Discovery and field surveys. PPV was first identified in northern Adams county in 1999 (Fig. 1, isolate numbers 1 and 2). The original find was a site consisting of commercial blocks of peach, plum, and apricot. Positive peach, plum, and apricot plants were identified using ELISA. The plum plants showed severe symptoms, including ringspots and mosaics. PPV-infected peach showed milder symptoms, while the infected apricot did not display any obvious symptoms. The disease incidences recorded at and near the original location were the highest observed in Pennsylvania, ranging up to $63 \%$ infection of trees. Following the original find of PPV a larger survey was conducted throughout Pennsylvania. In 2000, the survey was largely focused on commercial Prunus orchards but, in subsequent years, homeowner-grown and some wild Prunus spp. were included in the survey (Table 1). Over the 8 years of survey and eradication, the percentage of positive finds decreased consistently, with no positive samples found in 2007, 2008, 2009, and 2010.

Viral purification. The Penn 3 isolate was purified by two different methods from pea or $N$. benthamiana (21). The two purified virion preps were tested by rub inoculation on pea, $N$. benthamiana, and peach. The virions isolated from pea were not infectious on pea, peach, or $N$. benthamiana, whereas the virions isolated from $N$. benthamiana infected $100 \%$ of inoculated pea, $100 \%$ of inoculated N. benthamiana, and $50 \%$ of inoculated peach.

Sequence analyses. PPV isolates from Pennsylvania were initially characterized by immunology and partial sequence analysis as D strain isolates (22). These isolates in the field showed either fleeting or no symptoms on peach. Full-length genomic sequences were determined for seven PPV-Penn isolates by direct sequencing of RT-PCR products. All Pennsylvania isolates were D strain isolates, with 98.5 to $99.8 \%$ sequence identity (data not shown). Phylogenetic analyses of the seven full-length genomes indicated that the PPV-Penn isolates separated into two distinct clades (Fig. 2A). The two Penn isolate clades were more closely related to each other than they were to other European or Canadian PPV-D isolates. A phylogenetic analysis of the $3^{\prime}$ end of the PPV genome (including Chilean isolates) indicated that the western hemisphere isolates of PPV are more closely related to each other than they are to European isolates (Fig. 2B).

Phylogenetic analyses of individual genes resulted in different phylogenetic topologies, depending on the gene. The phylogenies for the P1 (Fig. 3A) and HC-Pro genes (Fig. 3B), for example, had very similar topologies to the phylogeny for the full-length genomes, with the minor exception that the Penn4 HC-Pro formed a separate group. The coat protein gene phylogeny,
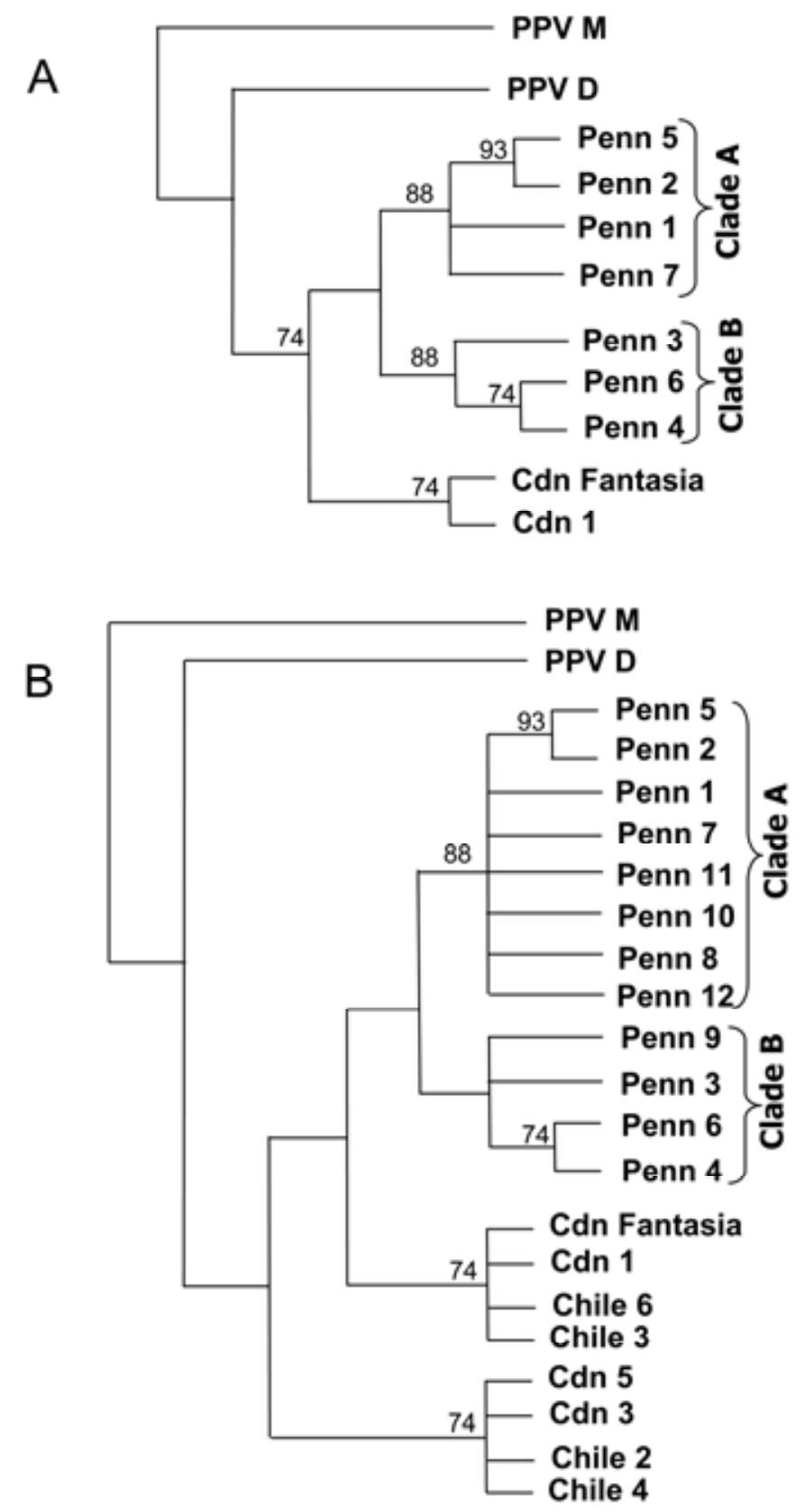

Fig. 2. Nucleotide phylogenies for A, full-length Plum pox virus (PPV) genomes; $\mathbf{B}$, the $3^{\prime}$ terminal 1,600 nucleotides, including a portion of the Nib gene, the coat protein gene, and the $3^{\prime}$ untranslated region.

TABLE 1. Plum pox virus (PPV) survey data for Adams, Cumberland, Franklin, and York Counties during 2000-2008z

\begin{tabular}{|c|c|c|c|c|c|c|}
\hline Year & Orchard samples & Homeowner samples & Other samples & Total samples & Total positives & Positive (\%) \\
\hline 2000 & 51,429 & 547 & 586 & 52,562 & 399 & 0.776 \\
\hline 2001 & 80,012 & 5,556 & 1,326 & 86,894 & 27 & 0.034 \\
\hline 2002 & 90,388 & 15,748 & 1,913 & 108,049 & 7 & 0.008 \\
\hline 2003 & 155,970 & 36,530 & 6,845 & 199,345 & 11 & 0.006 \\
\hline 2004 & 166,306 & 42,730 & 2,059 & 211,095 & 4 & 0.002 \\
\hline 2005 & 213,005 & 51,158 & 3,280 & 267,443 & 5 & 0.002 \\
\hline 2006 & 166,568 & 45,702 & 4,418 & 216,688 & 6 & 0.002 \\
\hline 2007 & 173,180 & 44,295 & 2,689 & 220,164 & 0 & 0 \\
\hline 2008 & 218,198 & 10,230 & 2,634 & 231,062 & 0 & 0 \\
\hline
\end{tabular}

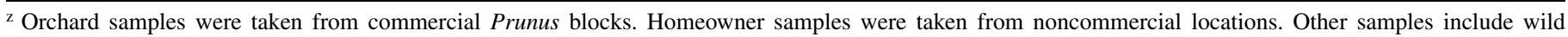
Prunus spp. from noncultivated areas. 
however, had a much different topology, where the relationships between the western hemisphere isolates were not maintained (Fig. 3D). In all, the majority of the individual gene phylogenies looked similar or identical to the tree for the full-length genome (data not shown).

EM. In leaf sap extracts, only Potyvirus sp.-like flexuous, rodshaped virus particles of uniform size and appearance were observed on uncoated grids. No evidence of other types of viruses was observed. All observations of negatively stained extracts suggested a very low virus concentration of PPV in infected Prunus leaves. Relatively few virions were observed on grids not coated with anti-PPV IgG (Fig. 4A), indicating either a low virus titer or interference by host components to virus binding. The number of virions observed on PPV-antibody-coated grids was proportional to the incubation time and supported the idea of low titer in Prunus spp. Maximum virus binding required overnight incubations of leaf extracts on anti-PPV IgG-coated nickel grids at $4^{\circ} \mathrm{C}$. Antibody-specific trapping enhanced accumulation of virions verifying the identity of the particles as PPV (Fig. 4B). No virions were observed when the same tissue extracts were incubated on grids coated with PDV antiserum as a control. Negatively stained single virions (Fig. 4C) from peach and plum leaf tissue extracts averaged $\approx 740 \pm 10 \mathrm{~nm}$ in length and $13 \mathrm{~nm}$ in diameter $(n=100)$. Two or more virions were frequently observed aggregated end to end in linear arrays in which it was difficult to
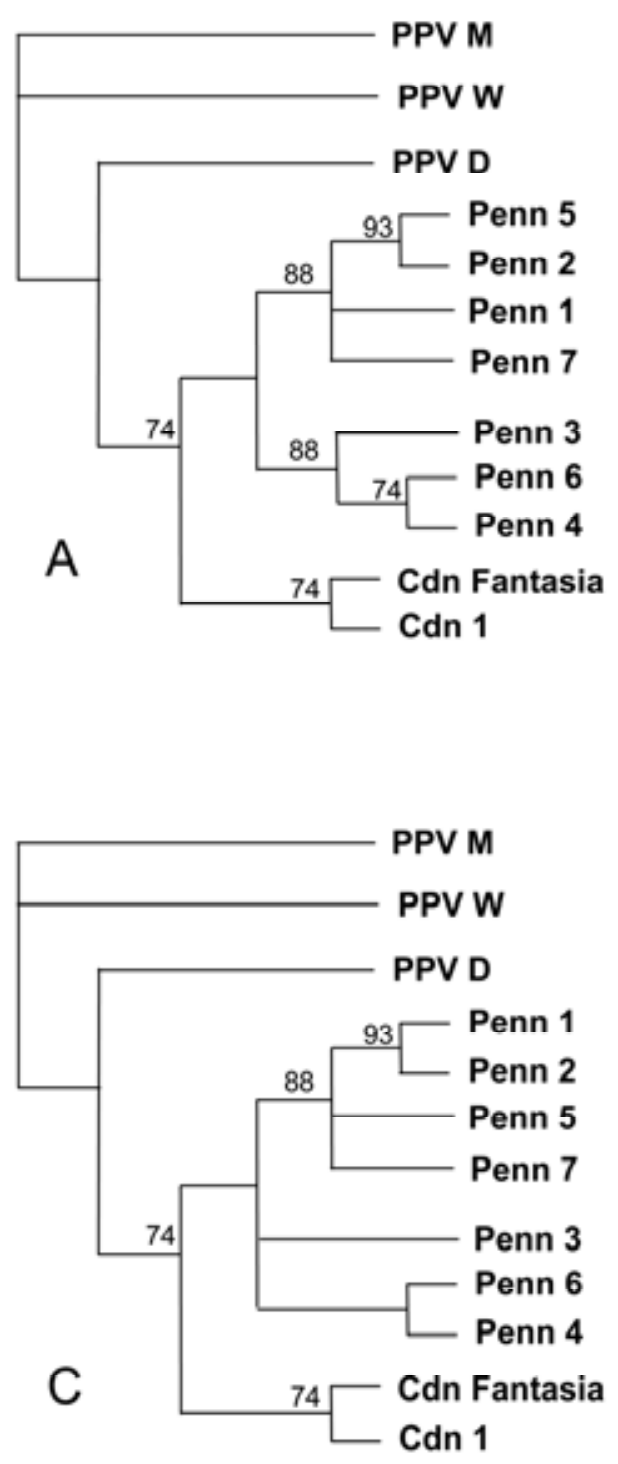

observe the ends of individual particles (Fig. 4D). Identity of the virions as PPV was further confirmed by specific immunogold labeling with anti-PPV antibody (Fig. 4E) but not with anti-PDV antibody.

In leaf sections, easily identified pinwheel viral inclusion bodies typical of Potyvirus sp. infection were observed in infected cells of PPV-infected peach, plum, and pea leaf tissue (Fig. 5A). In addition, in the inoculated pea, cytoplasmic laminate inclusions (Fig. 5B) and flexuous, rod-shaped particles were observed in $10 \%$ of the cells of the lower epidermis and the immediately adjacent spongy mesophyll. Both virions and laminate inclusions were frequently observed attached at one end to the cell plasmalemma, and laminate inclusions were especially concentrated around plasmodesmata (Fig. 5C and D). Flexuous rod-shaped particles, presumed to be PPV particles, were observed in the cytoplasm (Fig. 5E). These particles were most frequently observed to occur in small aggregates associated with laminate inclusions. In situ immunogold labeling of similar particles in infected pea leaf sections verified the identity of the particles as PPV (Fig. 5F).

Polyclonal anti-PPV specifically labeled the virions but did not concentrate on pinwheel or laminate inclusion bodies. Similar associations of virions and inclusion bodies were observed in PPV-infected peach and pea leaf tissue but occurred in many fewer cells in peach. Difficulty in locating virus-induced inclu-
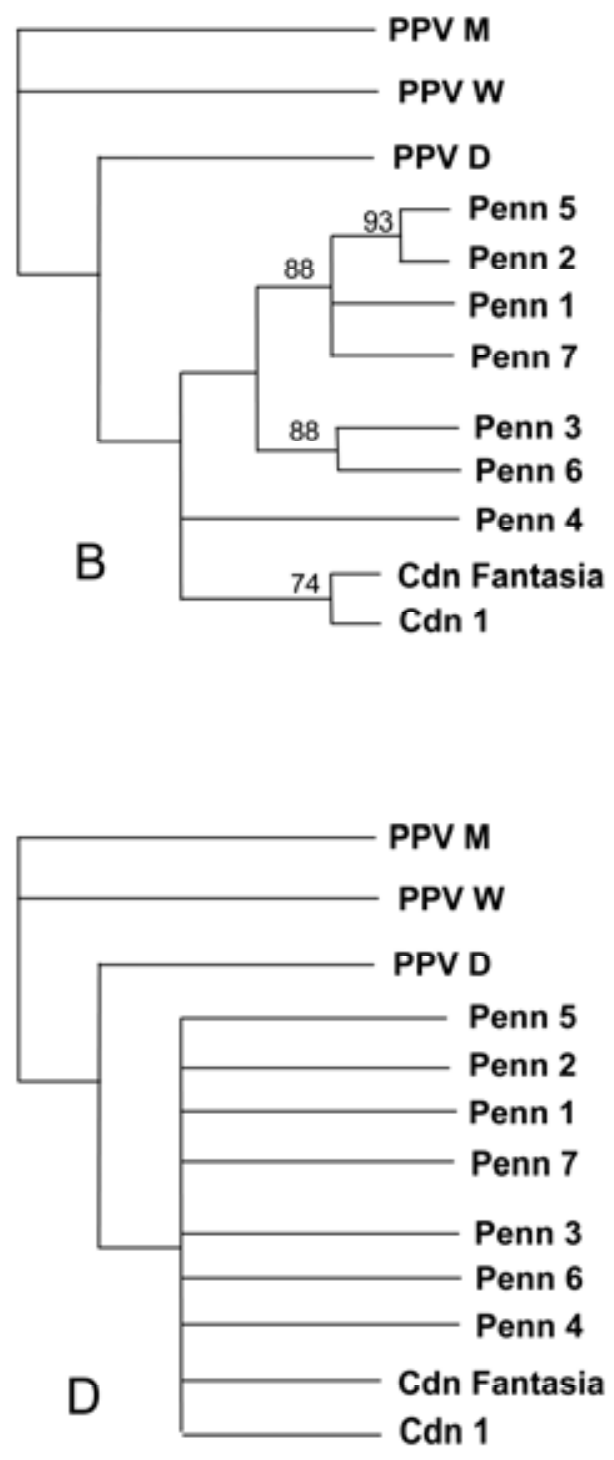

Fig. 3. Nucleotide phylogenies for A, the P1 gene; B, the HC-Pro gene; $\mathbf{C}$, the Nib gene; and $\mathbf{D}$, the coat protein gene. 
sions in PPV-infected cells in Prunus leaves corresponded to difficulty in visualizing virions in plant extracts. Observations suggested that relatively few Prunus leaf cells were infected, even when symptoms were obvious. No virions or inclusion bodies were observed in the upper epidermis or palisade parenchyma tissue in the same sections showing infected lower epidermis (data not shown). We failed to observe evidence of PPV infection in phloem parenchyma, companion cells, and sieve elements in veins located adjacent to infected mesophyll cells in several leaves examined. There was no evidence that PPV occurred in high concentrations in phloem associated with systemic spread. No viral inclusion bodies or associated virions were observed in any of three healthy control plants examined.

Herbaceous host range. PPV isolates Penn 3 and Penn 4 were tested on a limited host range of herbaceous plants (Table 2). Several diagnostic species were tested, along with a number of herbaceous species common to the eradication zone in Pennsylvania. Inoculated plants were tested for the presence of the virus
21 to 30 days postinoculation. PPV-Penn isolates demonstrated a relatively wide host range, including nine families and 26 species. In pea, the specific cultivar inoculated made a difference, because several cultivars were susceptible and other cultivars were not. However, in bean (Phaseolus vulgaris), none of the tested cultivars were susceptible. Many species were difficult to initially infect with the virus but became easier to infect, developed more severe symptoms, and developed symptoms more quickly with continued passage on the same host. For example, $<5 \%$ of $N$. benthamiana and pea plants became infected when initially inoculated with PPV from peach but continued passage on the same host resulted in improved inoculation rates and the development of more rapid and more severe symptoms (data not shown).

Aphid transmission. To test whether or not there were biological differences between the two clades of Pennsylvania PPV isolates, two representative isolates, Penn7 and Penn4 from clade A and B, respectively (Fig. 2), were used as source material for an
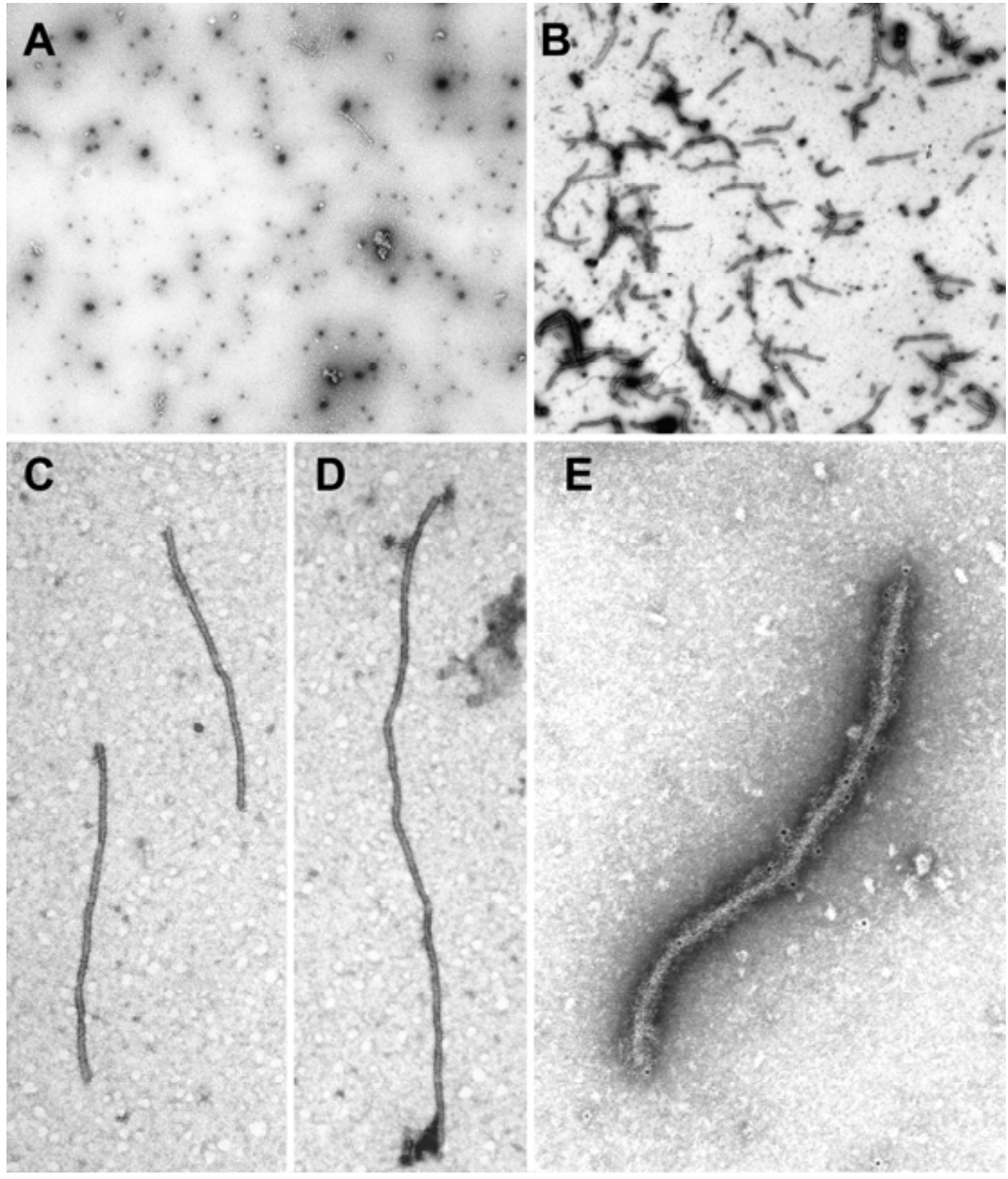

Fig. 4. Leaf sap extracts from infected peas. A, Leaf sap extracts on uncoated grids. B, Leaf sap extracts on grids Plum pox virus (PPV) antibody-coated grids. Maximum virus binding required overnight incubations of leaf extracts on anti-PPV immunoglobulin-G-coated nickel grids at $4^{\circ} \mathrm{C}$. C, Negatively stained single PPV virions extracts. D, Example of two PPV virions aggregated end to end. E, Immunogold labeling with anti-PPV antibody. 
aphid transmission test. In addition, a PPV-M isolate from Europe and a PPV-D isolate from Europe were used as inoculum sources. $M$. persicae and A. spiraecola were chosen as the aphid vectors. There were significant differences in aphid transmissibility between aphid species. M. persicae was the better vector for all isolates tested (Table 3 ). Using only 25 to 50 aphids per inocu- lated plant, $M$. persicae was able to successfully transmit PPV to 30 to $90 \%$ of inoculated plants. A. spiraecola, however, was only able to transmit successfully to 0 to $40 \%$ of inoculated plants when 50 to 100 aphids were used. The highest successful inoculation was $10 \%$ when 25 to $50 \mathrm{~A}$. spiraecola were used (data not shown). In addition to the differences between aphid vectors,
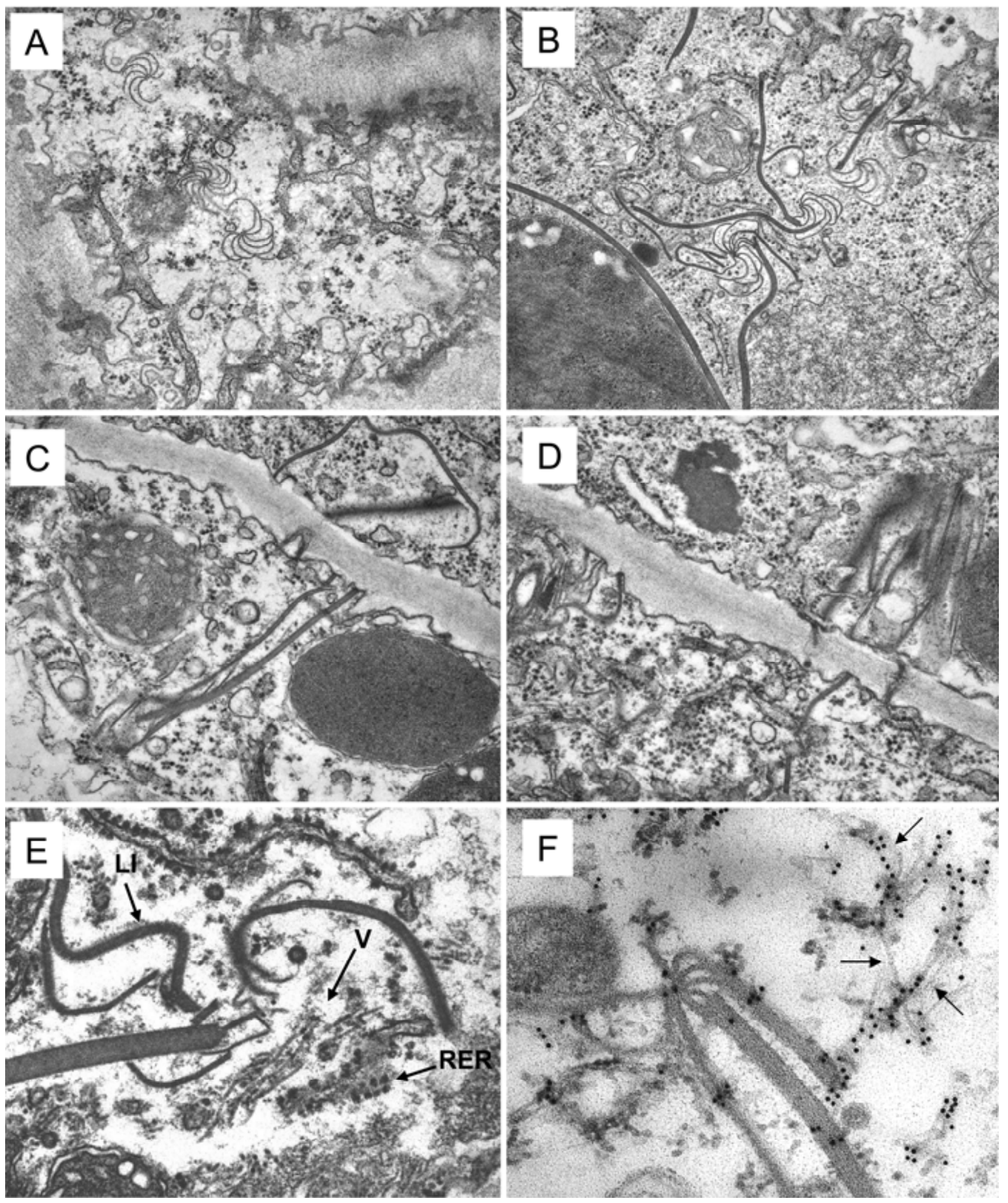

Fig. 5. Electron microscopy of Plum pox virus (PPV)-Penn infected leaf sections. A, Infected peach leaves. B, Infected pea leaves with flexuous, rod-shaped particles. C and D, PPV virions attached to the cell plasmalemma with laminate inclusions around plasmodesmata. E, Flexuous, rod-shaped particles, presumed to be PPV particles, observed in the cytoplasm. F, In situ immunogold labeling of similar particles in infected pea leaf sections. 
there were significant differences between PPV isolates when $M$. persicae was the vector. PPV-M was the most transmissible isolate, followed closely by Penn4. Penn7 had an intermediate level of $M$. persicae transmission, and the PPV-D isolate from Europe had the lowest level of transmission. Although the differences were not statistically significant, PPV-Penn4 consistently had the highest transmission rate using $A$. spiraecola.

The PPV isolates tested also had differences in terms of titer development 3 weeks postinoculation. PPV-M had the highest titers, PPV-Penn4 and -Penn7 had intermediate titer levels, and the European PPV-D had the lowest titers. Similar trends were seen in symptom development, where PPV-M caused the most severe symptoms, followed by PPV-Penn4, then PPV-Penn7, and European PPV-D. On the whole, peach plants inoculated using $A$. spiraecola developed less severe symptoms than those inoculated with $M$. persicae, even in plants inoculated with the identical PPV isolates. The titers associated with the infections generated with the two different vectors followed the same trend, with every isolate developing higher titers when inoculated by $M$. persicae.

\section{DISCUSSION}

PPV represents a significant threat to stone fruit production. As such, it is a well characterized virus, with considerable data available on the biology and genetics of the pathogen (23). In Europe, PPV-M is typically characterized as being the more aggressive strain, causing more severe damage and spreading faster on an epidemiological scale. The $\mathrm{M}$ strain isolates have been characterized as pathogens of peach and the D strain isolates as pathogens of plum. There is also speculation that the $M$ strain isolates are much better suited to aphid transmission than the D isolates. However, within the spectra of $\mathrm{M}$ and $\mathrm{D}$ strains, there is a fair amount of variability reported. Different authors report different host range and vector capabilities for isolates within the same strain, quite probably due to genetic differences in the specific isolates tested or differences in the aphid clones used for transmission $(5,27)$. As such, the objective of this work was to determine how closely the PPV-Penn isolates compared with the better-characterized European D strain isolates, in order to better inform eradication efforts.

TABLE 2. Herbaceous host range test for Plum pox virus (PPV)-Penn isolates

\begin{tabular}{|c|c|}
\hline Species & Result \\
\hline Arabidopsis thaliana & Positive \\
\hline Campanula rapunculoides & Positive \\
\hline Chenopodium amaranticolor & Positive \\
\hline C. murale & Positive \\
\hline C. foetidum & Positive \\
\hline C. quinoa & Positive \\
\hline Dimorphotheca aurantiaca & Positive \\
\hline Lamium album & Positive \\
\hline Lathyrus odoratus & Positive \\
\hline Lupinus albus & Positive \\
\hline Lycium barbarum & Positive \\
\hline Medicago lupulina & Positive \\
\hline Melilotus officinalis & Positive \\
\hline Nicotiana benthamiana & Positive \\
\hline N. megalosiphon & Positive \\
\hline N. occidentalis \#37 B & Positive \\
\hline N. physaloides & Positive \\
\hline N. tabacum & Positive \\
\hline Papaver somniferum & Positive \\
\hline Pisum sativum 'Colmo', 'Green Arrow', 'Super Snap', 'Burpeana Early', and 'Dwarf Grey’ & Positive \\
\hline Ranunculus acer & Positive \\
\hline R. arvensis & Positive \\
\hline Solanum dulcamara & Positive \\
\hline Taraxacum officinalis & Positive \\
\hline Trifolium pratense & Positive \\
\hline T. repens 'Ladino' & Positive \\
\hline Zinnia elegans 'Lilliput' and 'Dahlia' & Positive \\
\hline Albutilon theophrasti & Negative \\
\hline Alysicarpus ovalifolius & Negative \\
\hline Capsella bursa-pastoris & Negative \\
\hline Cucumis sativus 'National Pickling' & Negative \\
\hline Desmodium tortuosum & Negative \\
\hline Glycine $\max$ & Negative \\
\hline Gomphrena globosa & Negative \\
\hline Lycopersicum esculentum & Negative \\
\hline Medicago sativa & Negative \\
\hline N. bigelovii & Negative \\
\hline N. clevelandii & Negative \\
\hline N. debneyi & Negative \\
\hline N. edwardsonii & Negative \\
\hline N. rustica & Negative \\
\hline Phaseolus vulgaris 'Bountiful Pinto III', 'Red Kidney', and 'Top Crop' & Negative \\
\hline Physalis floridana & Negative \\
\hline Physalis heterophylla & Negative \\
\hline Pisum sativum 'Super Snapper', 'Super Bon', 'Wando', and 'Puget' & Negative \\
\hline Plantago major & Negative \\
\hline Solanum tuberosum & Negative \\
\hline Trifolium incarnatum & Negative \\
\hline T. subterraneum 'Mt. Barker' & Negative \\
\hline Vigna sinensis & Negative \\
\hline Zinnia elegans 'Aztec', 'Dwarf Mix', 'Double Dwarf Mix' & Negative \\
\hline
\end{tabular}


PPV was identified in Pennsylvania in 1999. The majority of positive finds $(90 \%)$ were relatively close to the original find, within a 30-square-mile area. The highest disease incidences were also found in this area, suggesting that this area represents the most likely point of introduction. Phylogenetic analysis of the full-length sequence of the PPV-Penn isolates indicated that they were all D-strain isolates belonging to two distinct clades. Both of these clades were present in the 30-square-mile area where PPV was likely introduced to Pennsylvania. Both of these clades were more closely related to each other than they were to any other PPV-D strain isolates, and further analysis indicates that the western hemisphere isolates of PPV-D are more closely related to each other than they are to PPV-D isolates from the rest of the world. This might serve as evidence for a single introduction of PPV-D into the western hemisphere, followed by subsequent spread. The presence of the two clades raises the possibility of multiple introductions of PPV into Pennsylvania but does not remove the possibility that both clades could have been brought simultaneously. A third possibility is that there was a single introduction of a single subgroup in Pennsylvania and that, over time, a second subgroup evolved. However, the limited spread and disease incidence in Pennsylvania suggest that the virus has been present for a limited amount of time, which would make such diversification difficult. As has been demonstrated in the past for other viruses, phylogenetic analyses of different genes result in different trees (28). This may be related to differences in selection pressures on different gene products, such as the HC-Pro of isolate Penn4. The HC-Pro of Potyvirus spp. is multifunctional, and the PPV HC-Pro is selected for at both the movement and replication levels $(30,31)$. The coat protein phylogeny for PPV lacked any sort of grouping. This is not completely surprising because other plant viruses have been known to lack phylogenetic definition in the coat protein region (28).

On a structural level, the PPV-Penn isolates closely resembled their European D strain counterparts. The EM evidence supports the identity of the virus particles observed as PPV, based on the characteristic Potyvirus sp.-like inclusions in leaves from PPVinfected trees (ELISA and PCR positive), the consistent occurrence of these inclusions associated with flexuous rod-shaped particles observed in cells of infected plants, and the specific attachment and immunogold labeling of virions with anti-PPV antisera. Ultrastructural analysis of particles isolated from infected hosts indicated 740-by-13-nm flexuous rods that were specifically labeled with polyclonal antibodies specific for PPV. Similar particles were labeled in situ with monoclonal antibody specific to PPV-D.

Ultrastructural observations supported real-time RT-PCR data suggesting lower virus titers in mature Prunus tissue. Pinwheel inclusions indicative of cell infections were only rarely observed in the infected Prunus hosts when mature leaves showing chlorotic symptoms typical of PPV infection were examined. This supported the ELISA data suggesting low virus titers in older Prunus leaves even when symptoms were obvious (23). Furthermore, the location of PPV in Prunus leaves may be tissue specific but tissue specificity associated with virus titer will need to be verified by more extensive studies. Pinwheel and laminar inclusions typical of Potyvirus sp. infection were observed in some leaf cells of all infected hosts examined. However, only in the hightiter pea host were inclusions readily observed in $\approx 10 \%$ of the lower epidermal cells and adjacent mesophyll (data not shown). Similarly, flexuous, rod-shaped virus particles were difficult to observe in cell cytoplasm of the Prunus tissues compared with the high-titer pea tissue, suggesting that PPV titer was much lower in the mature Prunus leaves.

In pea seedling leaf tissues, inoculated with PPV-Penn3, laminar inclusions were most obvious as long rod-like or rectangular inclusions most frequently attached to the cell plasmalemma membrane at one end (Fig. 4). Accumulations of these inclusions adjacent to plasmodesmata were obvious. Virions were frequently observed attached at one end to the plasmalemma, as well as to the laminar inclusions. The significance of these associations are unknown but deserve further study.

PPV isolates from Pennsylvania are capable of infecting a number of herbaceous hosts, corroborating host range reports for other PPV-D isolates. The direct contribution of these hosts to epidemiology of PPV has never been clearly demonstrated. The ability to back inoculate peach from infected herbaceous hosts suggests that these species could possibly be a potential reservoir. However, PPV has not been reported in herbaceous hosts in Pennsylvania (39), and Stobbs et al. (35) reported no PPV infections in a large survey of potential herbaceous hosts in Canada. Perhaps the difficulty in establishing an initial infection may play a role in limiting the potential reservoir in herbaceous hosts (39).

Despite the fact that all the Pennsylvania PPV isolates were clearly D-strain isolates, there were distinct biological differences between the Pennsylvania D isolates and previously described D isolates from Europe. Both the clade A (Penn4) and clade B (Penn7) isolates were more transmissible by $M$. persicae and caused more severe symptoms than a representative PPV-D isolate from Romania (PPV-22903A). PPV-Penn4 also developed higher titers than the PPV-22903A, whereas the PPV-Penn7 developed roughly equal titers to the PPV-22903A. In addition, there were distinct biological differences between PPV-Penn 4 and PPV-Penn7, supporting the phylogenetic differences. PPV-Penn4 was transmitted more efficiently by $M$. persicae, developed higher titers, and caused more severe symptoms than the PPV-Penn7. The European $\mathrm{M}$ strain isolate had better transmission rates by $M$. persicae and developed higher titers and more severe symptoms than any of the D strains tested. Regardless, the biological differences underscore the fact that minor changes in the genome can result in substantially different isolates, and that making regulatory decisions based on sequence similarity alone has definite risks.

Tests using A. spiraecola were less conclusive, largely because of the limited efficiency of inoculation. Of all the strains tested, PPV-Penn 4 was transmitted most efficiently by A. spiraecola; however, the differences were not statistically significant in the limited number of tests run. It is clear, however, that $M$. persicae

TABLE 3. Comparison of two Plum pox virus (PPV)-Penn isolates to a European D isolate from Romania (PPV-22903A, labeled as PPV-D in the table) and a European M strain isolate from Greece (PPV-M) ${ }^{\mathrm{Z}}$

\begin{tabular}{lcccc}
\hline & \multicolumn{4}{c}{ Isolate } \\
\cline { 2 - 5 } Vector & Penn4 & Penn7 & PPV-M & PPV-D \\
\hline Myzus persicae & & & & \\
Replicate 1 & $8 / 10$ & $2 / 10$ & $8 / 10$ & $3 / 10$ \\
Replicate 2 & $7 / 10$ & $4 / 10$ & $9 / 10$ & $2 / 10$ \\
Replicate 3 & $6 / 10$ & $6 / 10$ & $9 / 10$ & $1 / 10$ \\
Total & $21 / 30 \mathrm{a}$ & $12 / 30 \mathrm{~b}$ & $26 / 30 \mathrm{a}$ & $6 / 30 \mathrm{c}$ \\
Titer & 30.9 & 35.3 & 27.4 & 35.5 \\
Symptom & 1.67 & 2.00 & 2.35 & 1.67 \\
Aphis spiraecola & & & & \\
Replicate 1 & $9 / 10$ & $6 / 10$ & $1 / 10$ & $0 / 10$ \\
Replicate 2 & $4 / 10$ & $6 / 10$ & $1 / 10$ & $0 / 10$ \\
Replicate 3 & $4 / 10$ & $3 / 10$ & $3 / 10$ & $2 / 10$ \\
Total & $17 / 30 \mathrm{~b}$ & $15 / 30 \mathrm{~b}$ & $5 / 30 \mathrm{c}$ & $2 / 30 \mathrm{c}$ \\
Titer & 31.2 & 38.2 & 30.5 & 36.6 \\
Symptom & 1.35 & 1.27 & 2.20 & 1.00 \\
\hline
\end{tabular}

z Three replicates of aphid transmissions using Myzus persicae and Aphis spiraecola are shown. Titer in infected seedlings is measured by real-time reverse-transcription polymerase chain reaction (RT-PCR) 3 weeks postinoculation. Average titers measured by cycle threshold value from real-time RT-PCR for all infected plants of each isolate, separated by vector, are shown in the table. Average symptom rating for all infected plants of each isolate, separated by vector, is also shown in the table. Statistical significance for total infection rates (indicated by lowercase letters) was determined using analysis of variance. 
is a more efficient vector for all strains of PPV tested than $A$. spiraecola, corroborating other reports (11). It is interesting to note that plants inoculated using A. spiraecola developed much lower titers 3 weeks postinoculation, even when inoculated with the same isolate. This suggests that the vector efficiency might play a role in the progression of the disease. Possibly, the lessefficient vector delivers a significantly lower load of virus, delaying the course of infection or allowing host defenses to play a greater role.

It is interesting that PPV-M is typically described as being a more significant threat, due to more efficient transmission, more persistent symptoms, and greater damage (27). However, PPV-D strains have become much more widely spread globally. This possibly could be due to the latent nature of PPV-D infections. The lower titers and reduced transient symptoms make PPV-Dinfected trees more difficult to find and eradicate, whereas PPV-M outbreaks can be relatively easily identified and culled. Perhaps our understanding of PPV epidemiology is clouded by our preferential use of certain vectors in laboratory settings, and PPVD spread is not nearly as inefficient as believed. The data presented here suggest that, under the appropriate, conditions PPV-D strains can be transmitted as efficiently as PPV-M (Table 3, A. spiraecola transmissions). Alternatively, the worldwide spread of PPV-D strains over -M strains could simply be due to random chance; however, the consistent occurrence of new PPV outbreaks coming from D-strain origins (China, Kazakstahn, Norway, Pakistan, the United States, Canada, Chile, Argentina, and Tunisia) seems to contradict this possibility.

\section{LITERATURE CITED}

1. Atreya, P. L., Lopez-Moya, J. J., Chu, M. Atreya, C. D., and Pirone, T. P. 1995. Mutational analysis of the coat protein N-terminal amino acids involved in potyvirus transmission by aphids. J. Gen. Virol. 76:265-270.

2. Candresse, T., Dosba, F., Quiot, J. B., and Dunez, J. 1993. La Sharka: Le pointsur les recherches. Arboric. Fruit 464:30-35.

3. Carrington, J. C., Jensen, P. E., and Schaad, M. C. 1998. Genetic evidence for an essential role for potyvirus CI protein in cell-to-cell movement. Plant J. 14:393-400.

4. Dallot, S., Labonne, G., Boeglin, M., Quiot-Douine, L., T. Candresse, and Quiot, J. B. 1998. Peculiar Plum pox potyvirus D-populations are epidemic in peach trees. Acta Hortic. 472:355-364.

5. Dal Zotto, A., Ortego, J. M., Raigón, J. M., Caloggero, S., Rossini, M., and Ducasse, D. A. 2006. First report in Argentina of Plum pox virus causing sharka disease in Prunus. Plant Dis. 90:523.

6. Damsteegt, V. D., Scorza, R., Stone, A. L., Schneider, W. L., Webb, K., Demuth, M., and Gildow, F. E. 2007. Prunus host range of Plum pox virus (PPV) in the United States by aphid and graft inoculation. Plant Dis. 91:18-23.

7. Damsteegt, V. D., Waterworth, H. E., Mink, G. I., and Howell, W. E. 1997. Prunus tomentosa as a diagnostic host for detection of Plum pox virus and other Prunus viruses. Plant Dis. 81:329-332.

8. Diekmann, M., and Putter, C. A. J. 1996. FAO/IPGRI Technical Guidelines for the Safe Movement of Germplasm No. 15: Musa spp. IPGRI, Rome, Italy.

9. Fernandez, A., Guo, H. S., Saenz, P., Simon-Buela, L., DeCedron, M. G., and Garcia, J. A. 1997. The motif V of Plum pox potyvirus CI RNA helicase is involved in NTP hydrolysis and is essential for virus RNA replication. Nucleic Acids Res. 25:4474-4480.

10. García, J. A., Riechmann, J. L., Laín, S., Martín, M. T., Guo, H., Simon, L., Fernández, A., Domínguez, E., and Cervera M. T. 1994. Molecular characterization of Plum pox potyvirus. Bull. OEPP 24:543-553.

11. Gildow, F., Damsteegt, V., Stone, A., Schneider, W., Luster, D., and Levy, L. 2004. Plum pox in North America: Identification of aphid vectors and a potential role for fruit in virus spread. Phytopathology 94:868-874.

12. Glasa, M., Palkovics, L., Kominek, P., Labonne, G., Pittnerová, S., Kudela, O., Candresse, T., and Šubr, Z. 2004. Geographically and temporally distant natural recombinant isolates of Plum pox virus are genetically very similar and form a unique PPV subgroup. J. Gen. Virol. 85:2671-2681.

13. Gonzalez-Jara, P., Atencio, F. A., Martinez-Garcia, B., Barajas, D., Tenllado, F., and Diaz-Ruiz, J. R. 2005. A single amino acid mutation in the Plum pox virus helper component-protienase gene abolishes both synergistic and RNA silencing suppression activities. Phytopathology 95:894-900.
14. Gottwald, T. R. 2006. Epidemiology of sharka disease in North America EPPO Bull. 36:279-286.

15. Gottwald, T. R., Avinent, L., Llácer, G., Mendoza, A. H., and de Cambra, M. 1995. Analysis of the spatial spread of sharka (plum pox virus) in apricot and peach orchards in eastern Spain. Plant Dis. 79:266-278.

16. Herrera, G. 1994. Deteccion de la enfermedad de sharka (plum pox virus) on stone fruit trees in Chile. Acta Hortic. 472:393-399.

17. Hughes, G., Gottwald, T. R., and Levy, L. 2002. The use of hierarchical sampling in the surveillance program for Plum pox virus incidence in the United Sates. Plant Dis. 86:259-263.

18. James, D., and Varga, A. 2005. Nucleotide sequence analysis of Plum pox virus isolate W3174: Evidence of a new strain. Virus Res. 110:143-150.

19. James, D., Varga, A., Thompson, D., and Hayes, S. 2003. Detection of a new and unusual isolate of Plum pox potyvirus in plum (Prunus domestica). Plant Dis. 87:1119-1124.

20. Labonne, G., Lauriaut, F., Yvon, M., and Quiot, J. B. 1994. Aphid transmission of Plum pox potyvirus: Analysis of potential vectors in an apricot orchard. Bull. OEPP 24:681-690.

21. Laín, S., Riechmann, J. L., Méndez, E., and García, J. A. 1988. Nucleotide sequence of the $3^{\prime}$ terminal region of Plum pox potyvirus RNA. Virus Res. 10:325-342.

22. Levy, L., Damsteegt, V., and Welliver, R. 2000. First report of Plum pox virus (sharka disease) in Prunus persica in the United States. Plant Dis. $84: 202$.

23. López-Moya, J. J., Fernández-Fernández, M. R., Cambra, M., and García, J. A. 2000. Biotechnological aspects of Plum pox virus. J. Biotechnol. 76:121-136.

24. Nemchinov, L., Hadidi, A., Maiss, E., Cambra, M., Candresse, T., and Damsteegt, V. 1996. Sour cherry strain of Plum pox potyvirus (PPV): Molecular and serological evidence for a new subgroup of PPV strains. Phytopathology 86:1215-1221.

25. OEPP/EPPO. 2006. A review of Plum pox virus. Bull. OEPP/EPPO Bull. 36:201-349.

26. Palkovics, L., Wittner, A., and Balázs, E. 1995. Pathogen-derived resistance induced by integrating the plum pox virus coat protein gene into plants of Nicotiana benthamiana. Acta Hortic. 386:311-317.

27. Quiot-Douine, L. Boeglin, M., Dallot, S., Marie-Jeanne, V., and Quiot, J. B. 2001. Plum pox virus diversification observed in a small cluster of orchards. Acta Hortic. 550:85-90.

28. Roossinck, M. J. 2002. Evolutionary history of Cucumber mosaic virus deduced by phylogenetic analyses. J. Virol. 76:3382-3387.

29. Roy, A. S., and Smith, I. M. 1994. Plum pox situation in Europe. EPPO Bull. 24:515-523.

30. Saenz, P., Quiot, L., Quiot, J. B., Candresse, T., and Garcia, J. A. 2001. Pathogenicity determinants in the complex virus population of a Plum pox virus isolate. Mol. Plant-Microbe Interact. 14:278-287.

31. Saenz, P., Salvador, B., Simon-Mateo, C., Kasschau, K. D., Carrington, J. C., and Garcia, J. A. 2002. Host-specific involvement of the HC protein in the long-distance movement of potyviruses. J. Virol. 76:1922-1931.

32. Schneider, W. L., Sherman, D. J., Stone, A. L., Damsteegt, V. D., and Frederick, R. D. 2004. Specific detection and quantification of Plum pox virus by real-time fluorescent reverse transcription-PCR. J. Virol. Methods 120:97-105.

33. Serce, C. U., Candreese, T., Svanella-Dumas, L., Krizbai, L., Gazel, M., and Caglayan, K. 2009. Further characterization of a new recombinant group of Plum pox potyvirus isolates, PPV-T, found in orchards in the Ankara province of Turkey. Virus Res. 142:121-126.

34. Snover-Clift, K. L., Clement, P., Jablonski, R., and Tiffany, M. 2007. The discovery of Plum pox virus in New York State. Phytopathology 97:109110 .

35. Stobbs, L. W., van Driel, L., Whybourne, K., Carlson, C., Tulloch, M., and van Lier, J. 2005. Distribution of Plum pox virus in residential sites, commercial nurseries, and native plant species in the Niagara region. Plant Dis. 89:822-827.

36. Teycheney, P. Y., Tavert, G., Delbos, R., Ravelonandro, M., and Dunez, J. 1989. The complete nucleotide sequence of plum pox virus RNA (strain D). Nucleic Acids Res. 17:10115-10116.

37. Thielman, J., Yang, L., and Rochon D. 2006. Sequence analysis of isolates of the Canadian Plum pox virus, and comparisons to isolates from Europe and the United States. Can. J. Plant Pathol. 28:144-151.

38. Thompson, D., McCann, M., McLeod, M., Lye, D., Green, M., and James, D. 2001. First report of Plum pox potyvirus in Canada. Plant Dis. 85:97.

39. Wallis, C. M., Stone, A. L., Sherman, D. J., Damsteegt, V. D., Gildow, F. E., and Schneider, W. L. 2007. Adaptation of Plum pox virus to a herbaceous host (Pisum sativum) following serial passages. J. Gen. Virol. 88:2839-2845.

40. Wetzel, T., Candresse, T., Ravelonandro, M., Delbos, R. P., Mazyad, H., Aboul-Ata, A. E., and Dunez, J. 1991. Nucleotide sequence of the 3terminal region of the RNA of the E1 Amar strain of Plum pox potyvirus. J. Gen. Virol. 72:1741-1746. 